\title{
Coaggregation of FceRI with Fc $\gamma R$ IIIB Inhibits Degranulation but Not Induction of Bcl-2 Family Members A1 and Bim in Mast Cells
}

\author{
Maria Ekoff, MSc; Christine Möller, PhD; Zou Xiang, PhD; Gunnar Nilsson, PhD
}

\begin{abstract}
The aggregation of high-affinity immunoglobulin $\mathrm{E}(\mathrm{IgE})$ receptors $(\mathrm{Fc} \in \mathrm{RI})$ on mast cells is a critical event in the initiation of an allergic reaction. Coengagement of $F c \in R I$ with immunoglobulin $G$ (lgG) low-affinity receptor Fc $\gamma$ RIIB/CD32 inhibits degranulation and the release of inflammatory mediators from mast cells and has therefore been proposed as a new therapeutic approach for the treatment of allergies. In this study, we investigated whether Fc $\gamma$ RIIB, besides inhibiting degranulation, negatively regulates other signalling pathways downstream of $\mathrm{Fc} \in \mathrm{RI}$. For this, we determined the phosphorylation and/or expression of proteins involved in the regulation of mast-cell apoptosis. Coaggregation led to an attenuation of Akt phosphorylation but did not inhibit phosphorylation of transcription factor Foxo3a or its proapoptotic target, Bim. Similarly, FceRI-dependent expression of the prosurvival gene A1 was not affected by coaggregation. Our data demonstrate that coengagement of $F c \in R I$ and Fc $\gamma R$ IIB inhibits degranulation but not the signalling pathways regulating Bcl-2 family members Bim and A1.
\end{abstract}

Mast cells are critical effector cells mediating immunoglobulin E (IgE)-dependent allergic responses. Binding of an allergen to IgE, already bound to its high-affinity receptor FceRI on mast cells, leads to aggregation and subsequent activation. This initiates signalling events that typically result in degranulation, changes in gene expression, and the release of inflammatory mediators, contributing to acute and late-phase allergic

M. Ekoff, C. Möller, G. Nilsson-Department of Medicine, Clinical Immunology and Allergy Unit, Karolinska Institutet, Stockholm, Sweden; Z. XiangCambridge Institute for Medical Research, Cambridge, United Kingdom

Correspondence to: Dr. Gunnar Nilsson, Karolinska Institutet, Department of Medicine, Clinical Immunology and Allergy Unit, KS L2:04, SE-171 76 Stockholm, Sweden; E-mail: gunnar.p.nilsson@ki.se

DOI 10.2310/7480.2006.00011 responses. ${ }^{1-3}$ Fc $\in$ RI consists of a tetrameric protein complex, the IgE-binding amplifying $\alpha$ chain, a signalling $\beta$ chain, and two $\gamma$ chains. ${ }^{4}$ The $\beta$ and $\gamma$ subunits of the FceRI each contain an immunoreceptor tyrosine-based activation motif (ITAM), which is phosphorylated upon FceRI aggregation and which is both necessary and sufficient for receptor-induced signal transduction. ${ }^{5}$

Mast cells also express other Fc receptors, either constitutively or upon stimulation; among these, Fc $\gamma$ RI (CD64), Fc $\gamma$ RIIB (CD32), and Fc $\gamma$ RIII (CD16) are receptors for immunoglobulin $\mathrm{G}$ ( $\mathrm{IgG})$. Fc $\gamma \mathrm{RI}$ (high-affinity $\mathrm{IgG}$ receptor) and FcyRIII (low-affinity IgG receptor) are activating receptors, both containing ITAM, that initiate signalling upon aggregation. ${ }^{6,7}$ Fc $\gamma$ RIIB is a low-affinity receptor containing an immunoreceptor tyrosine-based inhibitory motif (ITIM), ${ }^{8}$ which negatively regulates the activating signal when coaggregated with activating receptors bearing an ITAM. ${ }^{9}$ The coaggregation results in the 
recruitment of the inhibitory signalling molecule SHIP, leading to the abrogation of the ITAMinduced activation. ${ }^{2,10,11}$

IgE-induced mast cell activation (ie, FceRI aggregation) is negatively regulated by coaggregation of Fc $\in$ RI with Fc $\gamma$ RIIB. ${ }^{9,12}$ The release of mediators and cytokines is inhibited in a process in which FceRI contributes to the ITIM-dependent inhibition of its own intracellular signalling. This is achieved by the FceRI-associated tyrosine kinase Lyn, which phosphorylates the FcyRIIB ITIM that recruits SHIP1, thus leading to Fc $\in \mathrm{RI}$ signal abrogation. ${ }^{11,13,14}$ The receptors interact with the Factin skeleton that enables FcyRIIB to recruit SHIP1, which is provided by filamin-1. Fc $\gamma$ RIIB is believed to negatively regulate Fc $\in \mathrm{RI}$ signalling in two ways: by facilitating the translocation of FceRI into the F-actin skeleton but also by concentrating SHIP1 at the site close to Fc $\in$ RI. ${ }^{15}$ Investigations of the mechanism by which SHIP mediates its FcyRIIB inhibitory function have also suggested p62 $2^{\mathrm{dok}}$ as a possible mediator of Fc $\gamma$ RIIB inhibition of FceRI signalling downstream of SHIP in mast cells. ${ }^{16}$

Fc $\in$ RI-mediated degranulation and release of mediators are inhibited when FceRI is coaggregated with FcyRIIB. ${ }^{12}$ In addition to elucidating the impact of coaggregation on mast-cell degranulation, this study has elucidated the effect on the activation of downstream signalling pathways involved in the regulation of mast-cell survival. The aggregation of FceRI induces rapid but transient phosphorylation of the signalling protein Akt and the forkhead transcription factor Foxo3a, known to regulate Bim expression at the transcriptional level. ${ }^{17}$ Phosphorylated Akt phosphorylates and thereby inactivates Foxo3a, which in its unphosphorylated state is located in the nucleus and acts as a transcription factor for Bim. Bim is a proapoptotic protein of the Bcl-2 family, involved in the regulation of mast-cell apoptosis. ${ }^{18,19}$ Another Bcl-2 family member of crucial importance for Fc $\in$ RI-mediated activationinduced mast-cell survival is A $1 .{ }^{20}$ Mast cells lacking A1 do not survive IgE receptor aggregation. ${ }^{20}$

In this study, we investigated if FceRImediated activation/expression of Akt, Foxo3a, $\mathrm{Bim}$, and A1 are inhibited when FceRI is coengaged with Fc $\gamma$ RIIB. We report here that although mast-cell degranulation is inhibited and the phos- phorylation of Akt is attenuated by the coaggregation of FceRI with Fc $\gamma$ RIIB, Foxo3a and Bim are still phosphorylated and up-regulated, respectively. We also demonstrate that the level of A1 messenger ribonucleic acid (mRNA) induced by FceRI is not significantly altered upon coaggregation with Fc $\gamma$ RIIB. Altogether, this indicates that only certain signalling pathways are affected by the coaggregation of Fc $\in$ RI with Fc $\gamma$ RIIB whereas others, closely related to cell survival, remain largely unaffected.

\section{Materials and Methods}

\section{Mast-Cell Cultures}

The murine mast cell line C57 $7^{21}$ (kindly provided by Dr. S.J. Galli, Stanford University, Stanford, CA) was cultured in RPMI-1640 medium supplemented with $10 \%$ fetal bovine serum (FBS), $2 \mathrm{mM}$ of L-glutamine, $100 \mu \mathrm{g} / \mathrm{mL}$ of penicillin/streptomycin, and $50 \mu \mathrm{M}$ of 2-mercaptoethanol. All culture reagents were obtained from Sigma Chemical Co. (St. Louis, MO). The C57 mast cell line has previously been characterized for Fc $\gamma$ RII/Fc $\gamma$ RIII expression. ${ }^{22}$

\section{Antibodies and Reagents}

AffiniPure rabbit anti-mouse $\mathrm{IgG}$ (RAM IgG), AffiniPure RAM IgG $\mathrm{F}\left(\mathrm{ab}^{\prime}\right)_{2}$ fragment (RAM $\left.\mathrm{F}\left(\mathrm{ab}^{\prime}\right)_{2}\right)$, and AffiniPure mouse anti-rat $\operatorname{IgG}(\mathrm{H}+\mathrm{L})$ $\mathrm{F}\left(\mathrm{ab}^{\prime}\right)_{2}$ fragment (MAR F $\left(\mathrm{ab}^{\prime}\right)_{2}$ ) were all purchased from Jackson ImmunoResearch Laboratories, Inc., Baltimore, MD. Purified RAM CD16/CD32 (Fc $\gamma$ III/II receptor) monoclonal antibody $(2.4 \mathrm{G} 2$ rat $\mathrm{Ab}$ ) was obtained from BD Biosciences, Heidelberg, Germany. Anti-rabbit IgE horseradish peroxidase-linked donkey anti-rabbit antibody was obtained from Amersham Biosciences, Uppsala, Sweden. LumiGLO reagent and peroxide, $10 \times$ cell lysis buffer, antibodies directed against phospho-Akt (serine [Ser] 473 and threonine [Thr] 308), and Akt were purchased from Cell Signaling Technology, Beverly, MA. Antibodies directed against phosphoFoxo3a (Thr 32 and Ser 253) and Foxo3a were 
obtained from Upstate Biotechnology, Lake Placid, NY. Anti-Bim antibody was purchased from Affinity Bioreagents, Inc., Golden, CO. $4 \times$ NuPAGE LDS Sample Buffer and $10 \times$ NuPAGE Sample Reducing Agent were obtained from Invitrogen, Carlsbad, CA; TriPure Isolation Reagent was purchased from Boehringer Mannheim, Mannheim, Germany; and Tween 20 was obtained from Merck Schuchardt, Hohenbrunn, Germany. All other reagents were purchased from Sigma Chemical Co.

\section{Antibody Conjugation}

MAR F(ab')2 was trinitrophenylated by incubation for 2 hours at room temperature with picrylsulfonic acid (2,4,6-trinitrobenzene sulfonic acid in borate-buffered saline, $\mathrm{pH}$ 8.0). The $\mathrm{TNP}_{7}{ }^{-}$ $\mathrm{F}\left(\mathrm{ab} \mathrm{b}^{\prime}\right) 2 \mathrm{MAR}$ obtained was purified on a prepacked disposable PD-10 column containing Sephadex G-25 medium (Amersham Biosciences).

\section{Mast-Cell Activation}

Mast_cells to be used for ribonuclease (RNAse) protection assay and $\alpha$-hexosaminidase release assay were resuspended in RPMI-1640 medium supplemented with $0.2 \%$ bovine serum albumin, $2 \mathrm{mM}$ of L-glutamine, and $100 \mu \mathrm{g} / \mathrm{mL}$ of penicillin/streptomycin. The cells were sensitized for 90 minutes at $37^{\circ} \mathrm{C}$ by the addition of $0.1 \mu \mathrm{g} / \mathrm{mL}$ of monoclonal anti-dinitrophenyl (anti-DNP) clone SPE-7 IgE mouse antibody (anti-DNP IgE). After washing, the cells were activated by the addition of either $45 \mu \mathrm{g} / \mathrm{mL}$ of RAM IgG (coaggregation of FceRI with Fc $\gamma$ RIIB) or $30 \mu \mathrm{g} / \mathrm{mL}$ of RAM $\mathrm{F}\left(\mathrm{ab}^{\prime}\right)_{2}$ (aggregation of $\mathrm{Fc} \in \mathrm{RI}$ ) at $37^{\circ} \mathrm{C}$ for the time periods indicated. Mast cells to be used for Western blot analysis were resuspended in the previously mentioned medium. The cells were sensitized for 90 minutes at $37^{\circ} \mathrm{C}$ by the addition of $0.1 \mu \mathrm{g} / \mathrm{mL}$ of the same IgE as previously mentioned or $0.1 \mu \mathrm{g} / \mathrm{mL}$ of the same IgE together with $5 \mu \mathrm{g} / \mathrm{mL}$ of $2.4 \mathrm{G} 2$ rat Ab. After being washed, the cells were activated by the addition of $10 \mu \mathrm{g} / \mathrm{mL}$ of TNP7-F(ab') mouse anti-rabbit (MAR) at $37^{\circ} \mathrm{C}$, causing either coaggregation of Fc $\gamma$ RIIB with Fc $\in$ RI or aggregation of Fc $\in$ RI, for the time periods indicated. The conjugated antibody, TNP7MAR $\mathrm{F}\left(\mathrm{ab}^{\prime}\right)_{2}$, functions as a multivalent antigen recognized by the FceRI-bound IgE but also recognizing bound 2.4G2 rat Ab. ${ }^{13}$ Aggregation with 2.4G2 rat Ab together with TNP7-MAR F $\left(\mathrm{ab}^{\prime}\right)_{2}$ does not cause degranulation, which indicates that expression of Fc $\gamma$ RIII (an activating low-affinity receptor for $\mathrm{IgG}$ ) on $\mathrm{C} 57$ cells does not interfere with our system (data not shown). In experiments in which the phosphorylation pattern of Akt and Foxo3a as well as the total amount of these two proteins were measured, the mast cells were starved for approximately 24 hours at $37^{\circ} \mathrm{C}$ in RPMI1640 medium supplemented with $0.5 \%$ FBS before sensitization and activation. For Bim expression experiments, the mast cells were resuspended in RPMI-1640 medium supplemented with $10 \%$ filtered FBS, $2 \mathrm{mM}$ of L-glutamine, $100 \mu \mathrm{g} / \mathrm{mL}$ of penicillin/streptomycin, and $50 \mu \mathrm{M}$ of 2 -mercaptoethanol during both sensitization and activation, which lasted for 24 hours.

\section{N-Acetyl- $\beta$-D-Hexosaminidase Release Assay}

For detection of the granular enzyme $\beta$-hexosaminidase, an enzymatic colorimetric assay was used. ${ }^{23}$ After 30 minutes of activation, $60 \mu \mathrm{L}$ of supernatant were transferred to a 96-well plate and mixed with an equal volume of substrate solution (7.5 mM of p-nitrophenyl-N-acetyl- $\beta$-D-glucosaminide dissolved in $80 \mathrm{mM}$ of citric acid, $\mathrm{pH}$ 4.5). The mixture was incubated on a rocker platform for 2 hours at $37^{\circ} \mathrm{C}$. After incubation, $120 \mu \mathrm{L}$ of glycine (0.2 M, pH 10.7) was added to each well, and the absorbance was measured with an Emax Precision Microplate Reader (Molecular Devices, Sunnyvale, CA).

\section{Western Blot Analysis}

The cells were lysed in SDS sample buffer (125 $\mathrm{mM}$ of tris-hydrochloric acid [pH 6.8], 4\% w/v SDS, $20 \%$ glycerol, $0.02 \% \mathrm{w} / \mathrm{v}$ bromphenol blue, and $50 \mathrm{mM}$ of dithiothreitol, added just before use) or in cell lysis buffer $(1 \times$ cell lysis buffer, $1 \mathrm{mM}$ of phenylmethylsulfonyl fluoride [PMSF]) before 
being sonicated on ice. The phosphorylation and/or the total amount of proteins of interest were studied by Western blot with a NuPAGE Bis-Tris Western gel (Invitrogen, Carlsbad, CA). After electrophoresis, the proteins were electrically transferred to a nitrocellulose membrane (Hybond ECL, Amersham Biosciences). All was performed according to the manufacturers' instructions. The membrane was incubated overnight at $4^{\circ} \mathrm{C}$ with the primary antibody and thereafter incubated with horseradish peroxidase-conjugated secondary antibody for 1 hour at room temperature. The proteins were visualized with an enhanced chemiluminescence system (LumiGLO) and exposure to a Hybond ECL film.

\section{RNAse Protection Assay}

TriPure isolation reagent was used for isolation of total cellular ribonucleic acid (RNA). An RNAse protection assay (RPA) was performed (according to RiboQuant System protocol) with an mAPO-2 multiprobe set (PharMingen, San Diego, CA). The gel was dried and exposed on Kodak film (Eastman Kodak Company, Rochester, NY) with intensifying screens at $-70^{\circ} \mathrm{C}$. Expression of RNA was detected with a phosphoimager device, and levels of expression were quantified with MacBAS 2.2 software (Fuji Photo Film Co., Ltd., Tokyo, Japan).

\section{Statistical Analysis}

We used an analysis of variance, followed by multiple comparison with the Wilcoxon matchedpairs test.

\section{Results}

\section{Coaggregation of FceRI with Fc $\gamma$ RIIB Inhibits IgE-Dependent Mast-Cell Degranulation}

To analyze the effect of Fc $\gamma$ RIIB-mediated inhibition of mast-cell activation, we used murine C57 mast cells known to express the receptors
FceRI and Fc $\gamma$ RIIB. C57 cells were sensitized with murine IgE and challenged with polyclonal $\mathrm{RAM} \mathrm{F}\left(\mathrm{ab}^{\prime}\right)_{2}$ to aggregate Fc $\in \mathrm{RI}$ or with RAM IgG to coaggregate FceRI and Fc $\gamma$ RIIB. The RAM $\mathrm{F}\left(\mathrm{ab}^{\prime}\right)_{2}$ induced activation of mast cells, leading to degranulation as measured by $\beta$-hexosaminidase release (Figure 1A). When FceRI was coaggregated with Fc $\gamma$ RIIB by the addition of RAM IgG, the release of $\beta$-hexosaminidase was inhibited (see Figure 1A).

In addition to the activation system whereby RAM IgG or RAM F( $\left.\mathrm{ab}^{\prime}\right)_{2}$ was added, we also used another system for Western blot analysis, one by which each receptor can be aggregated separately or coaggregated. C57 cells were sensitized with murine anti-DNP IgE and incubated with or without 2.4G2 rat Ab before challenge with TNPMAR F $\left(\mathrm{ab}^{\prime}\right)_{2}$, TNP-conjugated $\mathrm{F}\left(\mathrm{ab}^{\prime}\right)_{2}$ fragments of mouse anti-rat IgG. The conjugated antibody, TNP7-MAR F(ab'), functions as a multivalent antigen recognized by the FceRI-bound $\operatorname{IgE}$ but also recognizing Fc $\gamma$ RII-bound $2.4 \mathrm{G} 2$ rat Ab. ${ }^{13}$ The addition of TNP7-MAR F( $\left(\mathrm{ab}^{\prime}\right)_{2}$ will aggregate FceRI in cells sensitized with IgE, aggregate Fc $\gamma$ RIIB in cells sensitized with 2.4G2 rat Ab, and (as a consequence) coaggregate $F c \in R I$ and Fc $\gamma$ RIIB in cells sensitized with both $\operatorname{IgE}$ and 2.4G2 rat Ab. Since aggregation using 2.4G2 rat $\mathrm{Ab}$ together with TNP7-MAR F( $\left.\mathrm{ab}^{\prime}\right)_{2}$ does not cause degranulation, this indicates that expression of Fc $\gamma$ RIII (an activating low-affinity receptor for IgG) on C57 cells does not interfere with our system (data not shown). Although not as sufficient as the other system for causing degranulation, this system induced the activation of mast cells, causing degranulation, and showed inhibition upon coaggregation of FceRI with Fc $\gamma$ RIIB (see Figure 1B).

\section{Phosphorylation of Akt Is Attenuated by Coaggregation of Fc $\in R I$ with Fc $\gamma$ RIIB}

To assess the effects of coaggregating Fc $\in$ RI with Fc $\gamma$ RIIB on signals transduced downstream of Fc $\in$ RI, the phosphorylation pattern of Akt protein was investigated. Akt is a signal-transducing protein downstream of PI3-kinase, involved in a variety of cellular functions such as survival and 

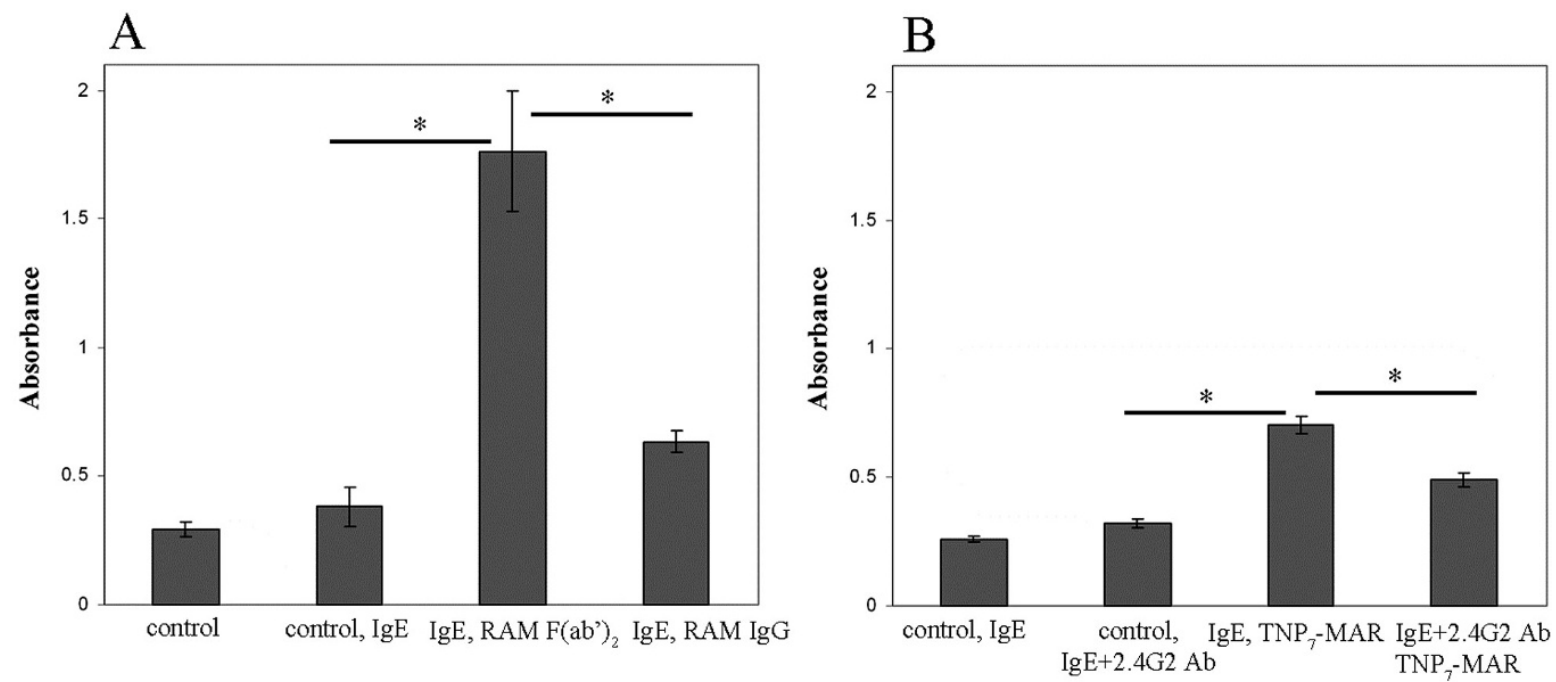

Figure 1 Inhibition of IgE-mediated mast-cell degranulation by Fc $\gamma$ RIIB. A, Mast cells were sensitized with 0.1 $\mu \mathrm{g} / \mathrm{mL}$ of monoclonal anti-dinitrophenyl (anti-DNP) clone SPE-7 immunoglobulin E (IgE) mouse antibody (antiDNP IgE) before being challenged with $30 \mu \mathrm{g} / \mathrm{mL}$ of rabbit anti-mouse (RAM) $\mathrm{F}(\mathrm{ab})_{2}$ or $45 \mu \mathrm{g} / \mathrm{mL}$ of RAM immunoglobulin G (IgG) for 30 minutes. Resting cells or cells incubated with $0.1 \mu \mathrm{g} / \mathrm{mL}$ of anti-DNP IgE served as a background control. The figure represents mast-cell activation estimated by $\beta$-hexosaminidase release as measured by absorbance. $B$, Mast cells were sensitized with $0.1 \mu \mathrm{g} / \mathrm{mL}$ of monoclonal anti-DNP clone SPE-7 IgE mouse antibody (anti-DNP IgE) and preincubated with or without $5 \mu \mathrm{g} / \mathrm{mL}$ of RAM CD16/CD32 (Fc $\gamma \mathrm{III} / \mathrm{II}$ receptor) monoclonal antibody (2.4G2 rat Ab), before challenge with $10 \mu \mathrm{g} / \mathrm{mL}$ of TNP-F(ab') ${ }_{2}$ mouse anti-rat (MAR) for $30 \mathrm{~min}$ utes. Cells incubated with $0.1 \mu \mathrm{g} / \mathrm{mL}$ of anti-DNP IgE or $0.1 \mu \mathrm{g} / \mathrm{mL}$ of anti-DNP IgE and $5 \mu \mathrm{g} / \mathrm{mL}$ of $2.4 \mathrm{G} 2 \mathrm{rat} \mathrm{Ab}$ served as a background control ( $n=6$; results are presented as mean \pm standard error of the mean). $* p<.05$.

metabolism. ${ }^{24,25}$ Via 3-phosphoinositide-dependent protein kinases, the PI3-kinase can activate Akt by phosphorylation at three different sites, two of which-threonine 308 ( $\mathrm{Thr} 308$ ) and serine 473 (Ser 473)—were investigated in this report. We compared the pattern of Akt phosphorylation at the Thr 308 and Ser 473 sites in cell lysates after Fc $\in$ RI aggregation or coaggregation of FceRI with Fc $\gamma$ RIIB. Fc $\in$ RI aggregation induced rapid phosphorylation of Akt at Thr 308; the maximum phosphorylation stage was reached within 1 minute, and phosphorylation decreased at 5 minutes. The phosphorylation of Akt after FceRI aggregation at Ser 473 was achieved within 1 minute and remained at a comparable level for 10 minutes before decreasing at 30 minutes (Figure 2). Considerable reductions of Akt phosphorylation at Thr 308 and Ser 473 were observed as early as 1 minute after coaggregation of Fc $\in$ RI with Fc $\gamma$ RIIB (see Figure 2).

\section{Coaggregation of FceRI with Fc $\gamma$ RIIB Does Not Affect the Phosphorylation of Transcription Factor Foxo3a}

Phosphorylated Akt phosphorylates and thereby inactivates the forkhead protein Foxo3a. ${ }^{26}$ The phosphorylation of Foxo3a prevents its translocation into the nucleus, where it acts as a transcription factor for certain genes. We investigated the phosphorylation of Foxo3a at sites Ser 253 and Thr 32. Phosphorylation of Foxo3a at Ser 253 occurred within 1 minute but reached background phosphorylation level again after 30 minutes (Figure 3). However, after rapid phosphorylation at site Thr 32 within 1 minute after FceRI aggregation, phosphorylation remained constant until $30 \mathrm{~min}$ utes had elapsed (see Figure 3). In contrast to the effect on Akt phosphorylation, coengagement of FceRI with Fc $\gamma$ RIIB did not affect either the levels of phosphorylation or the duration of the FceRIinduced Foxo3a phosphorylation (see Figure 3). 


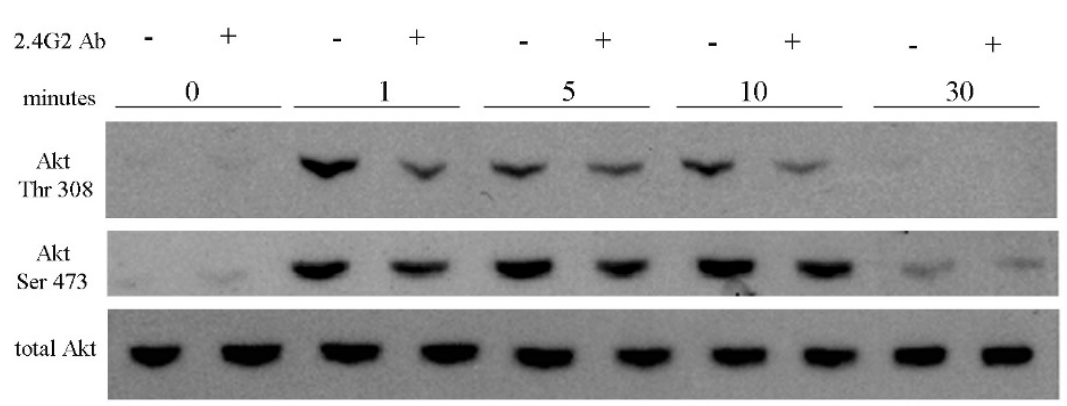

Figure 2 Reduction of immunoglobulin E (IgE)-dependent phosphorylation of Akt by FcyRIIB. C57 mast cells were activated as in Figure 1B for the indicated periods of time. Cell lysates were prepared, and the phosphorylation of Akt was analyzed by Western blot with the indicated antibodies. The result is representative of three independent experiments. Ser $=$ serine; $\mathrm{Thr}=$ threonine; $2.4 \mathrm{G} 2 \mathrm{Ab}=$ anti-mouse CD16/CD32 (FcyIII/II receptor) monoclonal antibody.

\section{FceRI-Induced Expression of Bim Is Not Inhibited by Coaggregation with Fc $\gamma$ RIIB}

A key regulator of apoptosis is the Bcl-2 family of proteins, which consists of proapoptotic and antiapoptotic proteins. Bim, one of the proapoptotic members, is transcriptionally regulated by Foxo $3 \mathrm{a},{ }^{27}$ and we recently showed that Bim is involved in the regulation of mast-cell apoptosis. ${ }^{18,19}$ Furthermore, Bim is induced upon aggregation of FceRI. ${ }^{18}$ Therefore, we next investigated if coaggregation of FceRI with Fc $\gamma$ RIIB would have an effect on Bim expression. After $F c \in R I$ aggregation and coaggregation of Fc $\in R I$ and Fc $\gamma$ RIIB, respectively, the two isoforms of $\operatorname{Bim}\left(\operatorname{Bim}_{\mathrm{EL}}\right.$ and $\left.\mathrm{Bim}_{\mathrm{L}}\right)$ were up-regulated to similar levels (Figure 4). Bim $\mathrm{EL}_{\mathrm{P}}$ consisted of two bands, owing to a shift in band motility; this shift of the Bim $_{\mathrm{EL}}$ band is probably the result of phosphorylation. ${ }^{19,28}$ The results herein demonstrate that Bim induced by FceRI aggregation is not affected by coaggregation with Fc $\gamma$ RIIB (see Figure 4).

\section{Coaggregation of FceRI with Fc $\gamma$ RIIB Does Not Affect the Induction of A1}

Apoptosis is regulated by members of the $\mathrm{Bcl}-2$ family. A1, one of the antiapoptotic Bcl-2 family members, is described as being important for the survival of mast cells during allergic reactions. ${ }^{20}$ To determine whether the coaggregation of FceRI with Fc $\gamma$ RIIB affects the induced transcriptional regu-

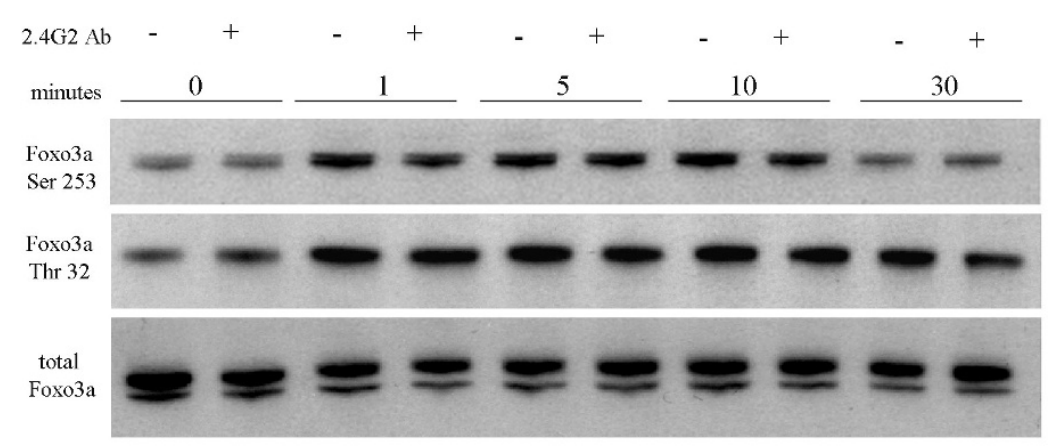

Figure 3 Phosphorylation of Foxo3a induced by $\mathrm{Fc} \in \mathrm{RI}$ and Fc $\gamma \mathrm{RIIB}$ or by Fc $\in$ RI alone. C57 mast cells were activated as in Figure 1B for the indicated periods of time. Cell lysates were prepared, and the phosphorylation of Foxo3a was analyzed by Western blot with the indicated antibodies. The result is representative of three independent experiments. Ser $=$ serine; $\mathrm{Thr}=$ threonine; $2.4 \mathrm{G} 2 \mathrm{Ab}=$ anti-mouse CD16/CD32 (FcyIII/II receptor) monoclonal antibody. 


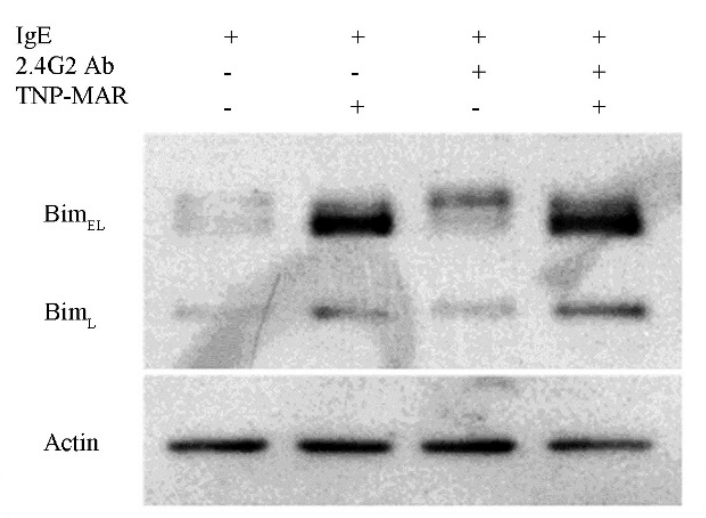

Figure 4 Expression of Bim induced by FceRI and Fc $\gamma$ RIIB or by FceRI alone. C57 mast cells were activated as in Figure 1B for 24 hours. Cells sensitized only with $0.1 \mu \mathrm{g} / \mathrm{mL}$ of anti-dinitrophenyl immunoglobulin $\mathrm{E}(\mathrm{lgE})$ and incubated with or without $5 \mu \mathrm{g} / \mathrm{mL}$ of rabbit anti-mouse CD16/CD32 (Fc $\gamma$ III/II receptor) monoclonal antibody (2.4G2 rat $\mathrm{Ab})$ were used as controls. Cell lysates were prepared, and the induction of Bim was analyzed by Western blot with the indicated antibodies. The result is representative of three independent experiments. $\mathrm{MAR}=$ mouse anti-rat; $\mathrm{TNP}=$ trinitrophenyl.

lation of A1, an RPA was performed. A1 was absent in cells incubated only with $\operatorname{IgE}$ but was substantially up-regulated after Fc $\in$ RI aggregation, as well as in cells where Fc $\epsilon$ RI had been coaggregated with Fc $\gamma$ RIIB for 6 hours (Figure 5). The A1 mRNA level in cells activated by FceRI aggregation had increased 12-fold, and coaggregation of Fc $\gamma$ RIIB with FceRI led to a ninefold increase when the signal was compared to control cells incubated with IgE alone (see Figure 5). Thus, although A1 up-regulation is slightly reduced after the coaggregation of FceRI with Fc $\gamma$ RIIB when compared to FceRI aggregation, the induction of $\mathrm{A} 1$ in cells after either coaggregation of FceRI with Fc $\gamma$ RIIB or FceRI aggregation (as compared to resting cells) was consistent in several experiments.

\section{Discussion}

Although coaggregation of FceRI with Fc $\gamma R I$ is known to inhibit mast-cell degranulation, the effect of coaggregation on other signalling pathways in mast cells has not been investigated previously. In
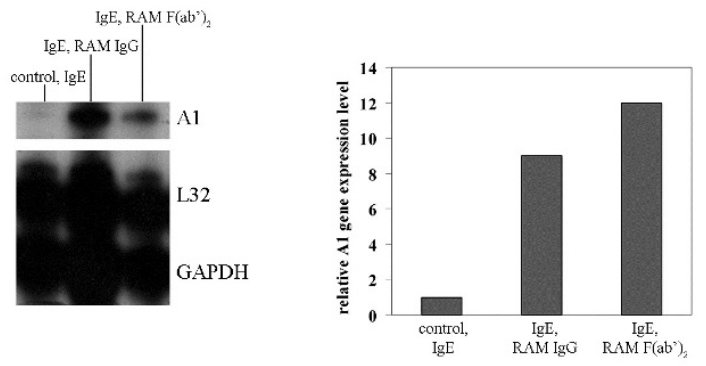

Figure 5 A1 expression induced by FceRI and Fc $\gamma$ RIIB or by $F c \in R I$ alone. A ribonuclease protection assay was performed on ribonucleic acid isolated from C57 cells activated as in Figure 1A for 6 hours, and quantifications of A1 transcript levels are shown relative to their corresponding levels GAPDH housekeeping gene. Data shown are representative of three separate experiments. $\operatorname{IgE}=$ immunoglobulin $\mathrm{E}$; $\mathrm{IgG}=$ immunoglobulin G; RAM = rabbit anti-mouse.

this study, we found that even though coaggregation of Fc $\in$ RI with Fc $\gamma$ RIIB inhibits degranulation and decreases the phosphorylation of Akt, we observed no effect on Foxo3a phosphorylation or Bim expression (see Figures 2, 3, and 4). Results from RPAs showed that the mRNA of A1 (an antiapoptotic Bcl-2 family member) was up-regulated both when mast cells were activated through FceRI aggregation and when they were activated through coaggregation of FceRI with Fc $\gamma$ RIIB (see Figure 5). Thus, Fc $\gamma$ RIIB inhibits some but not all signalling pathways downstream of Fc $\in$ RI.

One pathway affected by $F c \in R I$ aggregation is the PI3-K pathway, where PI3-K is phosphorylated and thereby activated..$^{5}$ Activated PI3-K can, via 3-phosphoinositide-dependent protein kinases or specific lipid products, phosphorylate the protein Akt. ${ }^{29,30}$ Phosphorylation of Ser 473 and/or Thr 308 enables Akt to carry out its multifunctional activities, which are involved in a variety of cellular functions such as survival and metabolism. ${ }^{24,25,31,32}$ Akt became rapidly phosphorylated at the two sites that were investigated after Fc $\in$ RI aggregation. The phosphorylation at Thr 308 was clearly diminished already after 5 minutes whereas the phosphorylation of Ser 473 remained for at least 20 minutes. This difference in phosphorylation between the two sites might reflect a strict regulation of phosphorylation of Akt. 
After coaggregation of Fc $\epsilon$ RI with Fc $\gamma$ RIIB, the phosphorylation of Akt was attenuated when compared to FceRI aggregation. Akt is more heavily phosphorylated after FceRI aggregation, but the duration of the phosphorylation does not change after coaggregation of Fc $\in$ RI with Fc $\gamma$ RIIB. These data are in line with data from earlier studies showing that coaggregation of Fc $\gamma$ RIIB and the $\mathrm{B}$-cell receptor (as well as coaggregation with the receptor for stem-cell factor Kit, present on mast cells) affects the PI3-K pathway and thereby inhibits the activation of Akt. ${ }^{33,34}$

Members of the transcription factor forkhead family, such as Foxo3a, can be inactivated through phosphorylation by activated Akt. ${ }^{26} \mathrm{We}$ found that Fce RI aggregation and Fc $\in$ RI coaggregation with FcyRII result in the same phosphorylation pattern of Foxo3a. This is an interesting observation because one might expect the phosphorylation of Foxo3a to decrease in response to less phosphorylated Akt being available. A possible explanation is that because the phosphorylation of Akt is not totally abrogated, there might still be enough to phosphorylate Foxo3a to the same extent. Another interesting feature is that phosphorylated Foxo3a is present in cells that are not activated by either Fc $\in$ RI aggregation or coaggregation of Fc $\gamma$ RIIB with Fc $\in$ RI. This suggests a natural equilibrium between phosphorylated and unphosphorylated Foxo3a in the cells, which is shifted toward phosphorylation upon activation. Akt is a major effector protein, and although the phosphorylation of Foxo3a by Akt does not seem to be affected, a pathway (or pathways) other than the one investigated might be where the inhibition of Akt phosphorylation plays a more crucial role.

A protein known to be under the transcriptional control of the forkhead transcription factor Foxo3a is Bim. ${ }^{27}$ We previously found Bim to be strongly increased upon Fce RI aggregation. ${ }^{18}$ After coaggregation of Fc $\gamma$ RIIB with FceRI or after FceRI aggregation, the two isoforms of Bim (BimEL and $\mathrm{Bim}_{\mathrm{L}}$ ) were up-regulated in comparison to unactivated control cells. The results demonstrate that FceRI-induced Bim up-regulation is not affected upon coaggregation with FcyRIIB. Bim ${ }_{\mathrm{EL}}$ consisted of two bands, probably due to phosphorylation. We have previously seen that stem- cell factor (SCF) promotes the survival of mast cells through inactivation of Foxo3a, preventing the up-regulation of Bim and leading to increased phosphorylation of Bim. Those results show that inhibition of Foxo3a and (consequently) Bim provides an important mechanism by which SCF acts to prevent apoptosis in mast cells. ${ }^{19}$

Antiapoptotic members of the Bcl-2 family are needed for cell survival. One of the murine prosurvival Bcl-2 family members is A1, which plays a prominent role in preventing apoptosis in a variety of cell systems. ${ }^{35,36}$ Previously, we demonstrated that mRNA levels for A1 are increased after FceRI aggregation and that $\mathrm{A} 1$ is critical for the activation-induced survival of mast cells. ${ }^{20} \mathrm{Sim}-$ ilarly, the human homologue bfl-1 is up-regulated in human mast cells upon Fce RI aggregation. ${ }^{37}$ We examined the mRNA induction of the antiapoptotic A1 protein after coaggregation of FceRI with Fc $\gamma$ RIIB; we found that A1 mRNA was up-regulated both when mast cells are activated through FceRI aggregation and when FceRI is coaggregated with Fc $\gamma$ RIIB. Our finding that both antiapoptotic A1 and proapoptotic Bim proteins are up-regulated as a result of Fc $\in \mathrm{RI}$ aggregation could be an explanation of why this activation results in cell death or survival in some experimental settings, since the fate of cells is likely to be influenced by the relative balance of these molecules.

The only treatment of allergic diseases that leads to long-lasting effects is allergen-specific immunotherapy. The immunologic mechanisms responsible for a successful treatment are still not fully defined. One hypothesis is that the antigenspecific IgG that increases in serum during treatment blocks antibodies, ${ }^{38}$ leading to possible coaggregation of FceRI with Fc $\gamma$ RIIB. The finding that allergic activity is inhibited by coaggregating Fc $\epsilon$ RI with Fc $\gamma$ RIIB by using a human Fc $\gamma$-Fc $\epsilon$ fusion protein highlights a new promising therapeutic approach to immunomodulation. ${ }^{39}$ The fusion protein showed antiallergic effects both in vitro and in vivo and was shown to inhibit IgEmediated activation of blood basophils and cord blood-derived mast cells. ${ }^{40}$

Furthermore, evidence for negative regulation of allergic responses by Fc $\gamma$ RIIB has been 


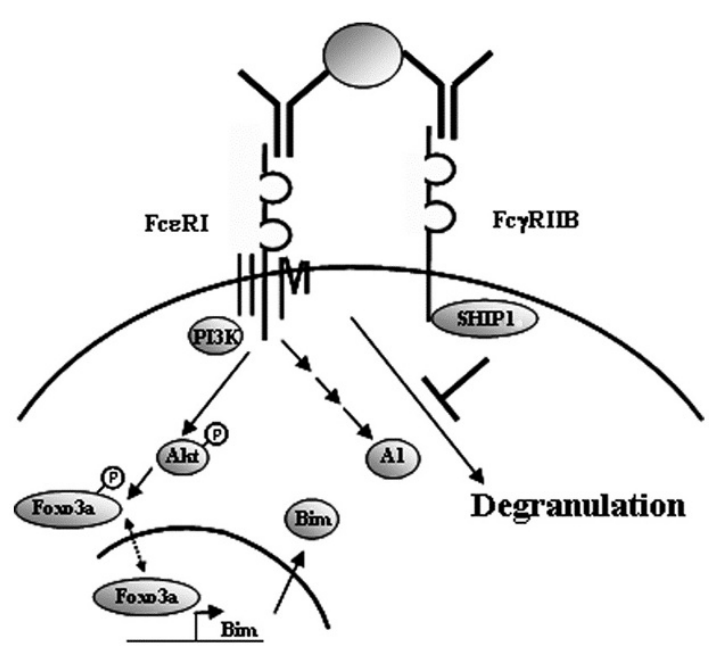

Figure 6 Schematic diagram showing the effect of coengagement of FceRI with Fc $\gamma$ RIIB. Coaggregation of FceRI with Fc $\gamma$ RIIB inhibits degranulation but not the induction of Bim and A1.

demonstrated by the use of Fc $\gamma$ RIIB-deficient mice. These mice produce more immunoglobulin than wild-type mice in response to immunization, ${ }^{41}$ in which this increase is partly due to the increase in $\mathrm{IgG} 1$. The negative regulation of IgG production by Fc $\gamma$ RIIB probably decreases the production of IgE. This would work in favour of reduced Fc $\in$ RI expression on the cells and less IgE being available for activation. ${ }^{42,43}$ Fc $\gamma$ RIIB-deficient mice also display more vascular permeability in the IgG-dependent passive cutaneous anaphylaxis reaction than do wildtype mice, indicating mast-cell activation of a greater extent than that seen in wild-type mice. ${ }^{41}$ During IgE- and IgG-dependent passive systemic anaphylaxis, the Fc $\gamma$ RIIB-deficient mice undergo increased hypothermia and death. ${ }^{44}$ These findings indicate an important role for Fc $\gamma$ RIIB on mast cells in down-regulating immediate hypersensitivity reactions as a result of anaphylactic mast-cell activation.

This report shows that although mast-cell degranulation is inhibited by coaggregation of FceRI with Fc $\gamma$ RIIB, other downstream signalling proteins that are closely related to cell survival remain largely unaffected. Figure 6 presents a schematic overview of how these processes could be separated in the cell. Our previous finding that both proapoptotic and antiapoptotic proteins are up-regulated as a result of Fc $\epsilon$ RI aggregation suggests that the fate of cells is likely to be based on the balance between these proteins. ${ }^{17}$

\section{Acknowledgements}

The authors would like to thank Dr. Marc Daëron for helpful discussions and advice, Prof. Birgitta Heyman and Mrs. Imma Brogren for help in the production of conjugated antibody, and Prof. Stephen Galli for C57 cells.

This work was supported by the Swedish Research Council-Medicine; the Swedish Cancer Foundation; the Bror Hjerpstedts Foundation; the Consul Th. C. Berghs Foundation; the Swedish Cancer and Allergy Fund; Ollie and Elof Ericsson's Foundation; King Gustav V's 80 Years Foundation; the Ellen, Walter, and Lennart Hesselmans Foundation; and the Karolinska Institutet.

\section{References}

1. Metcalfe DD, Baram D, Mekori YA. Mast cells. Physiol Rev 1997;77:1033-79.

2. Daeron M. Fc receptor biology. Annu Rev Immunol 1997;15:203-34.

3. Ott VL, Cambier JC. Activating and inhibitory signaling in mast cells: new opportunities for therapeutic intervention? J Allergy Clin Immunol 2000;106:429-40.

4. Blank U, Ra C, Miller L, et al. Complete structure and expression in transfected cells of high affinity IgE receptor. Nature 1989;337:187-9.

5. Turner H, Kinet JP. Signalling through the highaffinity $\operatorname{IgE}$ receptor Fc epsilonRI. Nature 1999;402(6760 Suppl):B24-30.

6. Hulett MD, Hogarth PM. Molecular basis of Fc receptor function. Adv Immunol. 1994;57:1-127.

7. Weiss A, Littman DR. Signal transduction by lymphocyte antigen receptors. Cell 1994; 76:263-74.

8. Bolland S, Ravetch JV. Inhibitory pathways triggered by ITIM-containing receptors. Adv Immunol 1999;72:149-77.

9. Daeron M, Latour S, Malbec O, et al. The same tyrosine-based inhibition motif, in the intracy- 
toplasmic domain of Fc gamma RIIB, regulates negatively BCR-, TCR-, and FcR-dependent cell activation. Immunity 1995;3:635-46.

10. Ravetch JV, Bolland S. IgG Fc receptors. Annu Rev Immunol 2001;19:275-90.

11. Ono M, Bolland S, Tempst P, Ravetch JV. Role of the inositol phosphatase SHIP in negative regulation of the immune system by the receptor Fc(gamma)RIIB. Nature 1996;383:263-6.

12. Daeron M, Malbec O, Latour S, et al. Regulation of high-affinity IgE receptor-mediated mast cell activation by murine low-affinity $\operatorname{IgG}$ receptors. J Clin Invest 1995;95:577-85.

13. Malbec O, Fong DC, Turner M, et al. Fc epsilon receptor I-associated lyn-dependent phosphorylation of Fc gamma receptor IIB during negative regulation of mast cell activation. J Immunol 1998;160:1647-58.

14. Huber M, Helgason CD, Damen JE, et al. The src homology 2-containing inositol phosphatase (SHIP) is the gatekeeper of mast cell degranulation. Proc Natl Acad Sci U S A. 1998; 95:11330-5.

15. Lesourne R, Fridman WH, Daeron M. Dynamic interactions of Fc gamma receptor IIB with filamin-bound SHIP1 amplify filamentous actindependent negative regulation of Fc epsilon receptor I signaling. J Immunol 2005;174:1365-73.

16. Ott VL, Tamir I, Niki M, et al. Downstream of kinase, p62(dok), is a mediator of Fc gamma IIB inhibition of Fc epsilon RI signaling. J Immunol 2002;168:4430-9.

17. Alfredsson J, Moller C, Nilsson G. IgE-receptor activation of mast cells regulates phosphorylation and expression of forkhead and Bcl-2 family members. Scand J Immunol 2006;63:1-6.

18. Alfredsson J, Puthalakath H, Martin H, et al. Proapoptotic Bcl-2 family member Bim is involved in the control of mast cell survival and is induced together with Bcl-XL upon IgE-receptor activation. Cell Death Differ 2005;12:136-44.

19. Möller C, Alfredsson J, Engström M, et al. Stem cell factor promotes mast cell survival via inactivation of FOXO3a-mediated transcriptional induction and MEK-regulated phosphorylation of the proapoptotic protein Bim. Blood 2005;106:1330-6.

20. Xiang Z, Ahmed AA, Möller C, et al. Essential role of the prosurvival bcl-2 homologue A1 in mast cell survival after allergic activation. J Exp Med 2001;194:1561-9.
21. Young JD, Liu CC, Butler G, et al. Identification, purification, and characterization of a mast cellassociated cytolytic factor related to tumor necrosis factor. Proc Natl Acad Sci U S A 1987;84:9175-9.

22. Takizawa F, Adamczewski M, Kinet JP. Identification of the low affinity receptor for immunoglobulin $\mathrm{E}$ on mouse mast cells and macrophages as Fc gamma RII and Fc gamma RIII. J Exp Med 1992;176:469-75.

23. Dastych J, Hardison MC, Metcalfe DD. Aggregation of low affinity $\operatorname{IgG}$ receptors induces mast cell adherence to fibronectin: requirement for the common FcR gamma-chain. J Immunol 1997;158:1803-9.

24. Hemmings BA. Akt signaling: linking membrane events to life and death decisions. Science 1997;275:628-30.

25. Coffer PJ, Jin J, Woodgett JR. Protein kinase B (c-Akt): a multifunctional mediator of phosphatidylinositol 3-kinase activation. Biochem $\mathrm{J}$ 1998;335(Pt 1):1-13.

26. Brunet A, Bonni A, Zigmond MJ, et al. Akt promotes cell survival by phosphorylating and inhibiting a forkhead transcription factor. Cell 1999;96:857-68.

27. Dijkers PF, Medema RH, Lammers JW, et al. Expression of the pro-apoptotic Bcl-2 family member Bim is regulated by the forkhead transcription factor FKHR-L1. Curr Biol 2000;10:1201-4.

28. Shinjyo T, Kuribara R, Inukai T, et al. Downregulation of $\mathrm{Bim}$, a proapoptotic relative of $\mathrm{Bcl}-$ 2 , is a pivotal step in cytokine-initiated survival signaling in murine hematopoietic progenitors. Mol Cell Biol 2001;21:854-64.

29. Klippel A, Kavanaugh WM, Pot D, Williams LT. A specific product of phosphatidylinositol 3kinase directly activates the protein kinase Akt through its pleckstrin homology domain. Mol Cell Biol 1997;17:338-44.

30. Toker A, Cantley LC. Signalling through the lipid products of phosphoinositide-3-OH kinase. Nature 1997;387:673-6.

31. Alessi DR, Andjelkovic M, Caudwell B, et al. Mechanism of activation of protein kinase $B$ by insulin and IGF-1. EMBO J 1996;15:6541-51.

32. Alessi DR, James SR, Downes CP, et al. Characterization of a 3-phosphoinositide-dependent protein kinase which phosphorylates and activates protein kinase B alpha. Curr Biol 1997;7:261-9. 
33. Aman MJ, Lamkin TD, Okada $\mathrm{H}$, et al. The inositol phosphatase SHIP inhibits Akt/PKB activation in B cells. J Biol Chem 1998; 273:33922-8.

34. Malbec O, Schmitt C, Bruhns P, et al. Src homology 2 domain-containing inositol 5-phosphatase 1 mediates cell cycle arrest by FcgammaRIIB. J Biol Chem 2001;276:30381-91.

35. Noble KE, Wickremasinghe RG, DeCornet C, et al. Monocytes stimulate expression of the Bcl-2 family member, A1, in endothelial cells and confer protection against apoptosis. J Immunol 1999;162:1376-83.

36. Lin EY, Orlofsky A, Wang HG, et al. A1, a Bcl2 family member, prolongs cell survival and permits myeloid differentiation. Blood 1996;87:983-92.

37. Xiang Z, Möller C, Nilsson G. IgE-receptor activation induces survival and expression of the prosurvival gene bfl-1 in human mast cells but not in basophils. Allergy 2006. [DOI]

38. Flicker S, Valenta R. Renaissance of the blocking antibody concept in type I allergy. Int Arch Allergy Immunol 2003;132:13-24.
39. Zhu D, Kepley CL, Zhang M, et al. A novel human immunoglobulin Fc gamma Fc epsilon bifunctional fusion protein inhibits Fc epsilon RImediated degranulation. Nat Med 2002;8:518-21.

40. Saxon A, Zhu D, Zhang K, et al. Genetically engineered negative signaling molecules in the immunomodulation of allergic diseases. Curr Opin Allergy Clin Immunol 2004;4:563-8.

41. Takai T, Ono M, Hikida M, et al. Augmented humoral and anaphylactic responses in Fc gamma RII-deficient mice. Nature 1996;379:346-9.

42. Yamaguchi M, Lantz CS, Oettgen HC, et al. IgE enhances mouse mast cell Fc(epsilon)RI expression in vitro and in vivo: evidence for a novel amplification mechanism in IgE-dependent reactions. J Exp Med 1997;185:663-72.

43. MacGlashan D Jr, McKenzie-White J, Chichester K, et al. In vitro regulation of FcepsilonRIalpha expression on human basophils by IgE antibody. Blood 1998;91:1633-43.

44. Ujike A, Ishikawa Y, Ono M, et al. Modulation of immunoglobulin (Ig)E-mediated systemic anaphylaxis by low-affinity Fc receptors for IgG. J Exp Med 1999;189:1573-9. 